\title{
128 船首部における壁面摩擦応力の画像計測
}

\author{
大阪府立大学 松村剛志, 奥野武俊, 西尾 茂, 田原祐介, 前山直子○
}

\section{Image Measurement of Wall Friction at Bow Hull}

\author{
T. MATSUMURA*, T. OKUNO**, S. NISHIO**, Y. TAHARA** and N. MAEYAMA**
}

A non-contact measurement method for wall friction distribution using oil film has been already proposed by the authors. The present paper describes the result of the application of the method to the fore part of small ship model. Since the boundary layer near the bow is generally very thin, it is impossible to use the normal device for measuring the wall friction, such as Preston tube. This method enable to measure the wall friction distribution and limiting streamline. The effect of turbulent stimulator is also examined through the experiment.

\section{1 緒 言}

物体表面に油膜を塗布して限界流線を可視化する手法は油膜法と呼ばれ、古くから多く

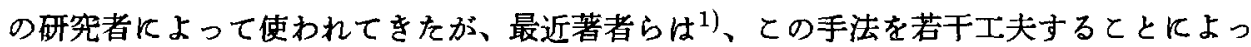
て油膜の微少な移動量を画像から求める方法を示し、その結果から壁面摩摺応力分布を計 測する手法を開発した。

著者らが提案した手法は、物体壁面に薄く塗布した油の移動量をCCDカメラで撮影し た画像を使って非接触計測するものである。一般に、船首付近では境界層厚さが非常に薄 レ上、船首部形状はバルバスバウなどを使った複雑な 3 次元曲面になっているため、プレ ストン管などの使用は容易でない。もちろん、提案されている手法を新しい計測法として 確立するためには、解决しなければならない問題も残されているが、現段階でも壁面摩擦 応力の分布形状や、摩擦力べクトルや限界流線は求めるととがでをる。

本論文は、との手法を使って船体模型の船首付近における壁面摩擦応力分布を計測した 結果につレて述へたもので、船体模型の実験によく用レられる乱流促進のためのスタッド を使った場合と、使わない場合の結果を比較して、これらが壁面摩摖に与える影響を調查 し、さらに CFDKよる数値計算結果とも比較検討したものである。

\section{2 壁面摩擦応力の計測}

著者らが提案している、壁面摩擦応力の画像計測手法は以下のよ5なむのである。すな わち、まず船体表面上にェンジンオイルを薄く（約 $25 \mu$ 程度の厚さ）一様に塗布し、その 上にカーボンブラックなどの嵃料を含んだ流動バラフィンを小量散布した油膜を作る。と の油膜を適当な時間間隔で 2 枚撮影し、それを時空間徽分法 ${ }^{2)}$ と呼ばれる画像解析法によっ

* Garduate Student, University of Ósaka Prefecture, Gakuen-cho, Sakai, Osaka 593, Japan

** University of Osaka Prefecture

*** Undergraduate Student 
(a)

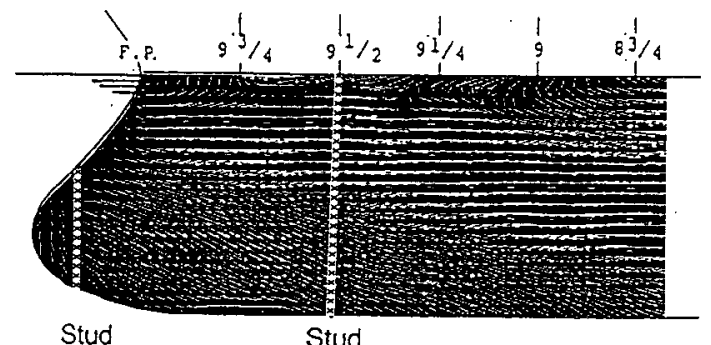

Stud

(b)

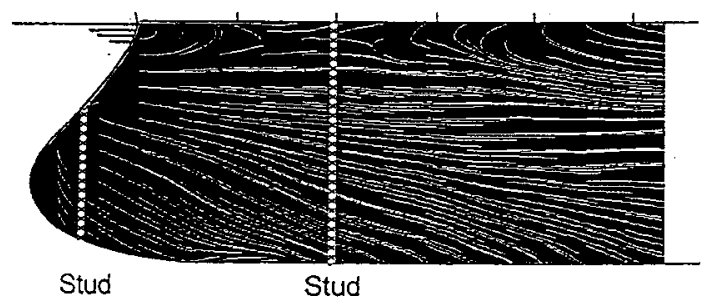

(c)

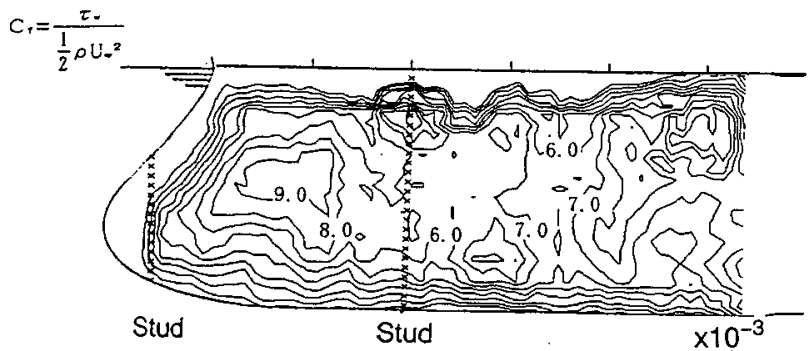

Fig.1 Measured results with 2 row turbulent stimulator.

(a)Displacement vectors of oil, (b) Limiting streamline,

(c)Wall friction distribution (longitudinal component).

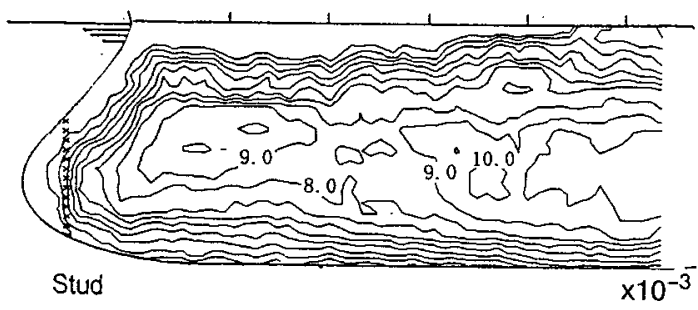

Fig.2 Measured wall friction distribution with 1 row turbulent stimulator. 


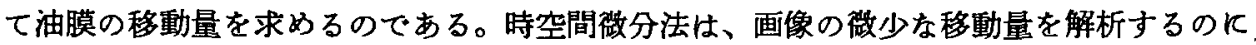
適しており、空間分解能の高的手法として知られてまり、著者らによって流場の速度分布 計測に使われ、その有効性が示されている゙2もののである油膜は必ずしも長時間にわたっ て移動するとは限らないので、2 枚の撮影時間間隔は長くならならととが必要で、油膜の 移動量は肉眼で識別できないほど小さくなるので時空間砤分法が有効である。なお、著者 らによって求められた油膜の移動量と壁面摩擦力の関係式には、摩擦力の小さ的領域で難 点があるものの、船首付近における摩察応力は比較的大きな值であり、本研究では壁面摩

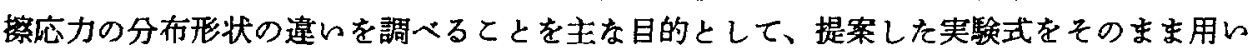
ている。

\section{3 船首付近の壁面摩擦底力分布}

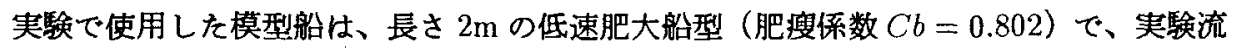

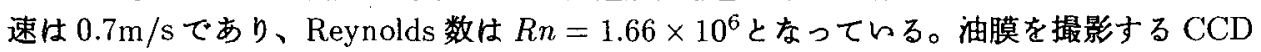
カタラは船体の横方向にセットされ、撮影する範囲はレンズの収差などを修正する必要が ないほどに小さく定めてある。したがって、得られる表面上のベクトルは船体中央面に投 影したものとなっている。

まず、船首 S.S.ー $\frac{1}{10}$ および S.S. $9 \frac{1}{2}$ K $5 \mathrm{~mm}$ 間隔、壁面からの高さ約 $1 \mathrm{~mm}$ でスタッドが 打ち込まれている場合の結果を示す。Fig.1(a) は油膜の移動量をべクトル表示したもの、 Fig.1(b)はそのぺクトル値を積分して流線を求めを結果である。この結果は、眓には示し ていないが、通常の油膜法による可視化夷験結果と非常によく似ている。Fig.1(c) 計測 された摩擦応力の $x$ 方向成分（船の前進方向）の等值線図で、第 2 列目のスタッド前後で 摩擦応力が変化しており、とてで乱流要移が起とっている可能性を示している。Fig.2は、 第 1 列目のスタッドのみを使った場合の結果で、バルブ付近の様子は Fig.1 とよく似てい るが、S.S.9 $\frac{1}{2}$ 後方では若干の違いが認められる。

さらに、Fig.3(a)〜 (c)は、スタッドを使わない場合の同様の結果である。流れは全体に わたって層流と思われるので、摩撩応力を求めろ険定曲線は上記のものとは別のものを使 らでをであるが、とてではこれを無視してすべて同じ検定曲線を使ってみた。その結果は Fig.3(c) で、全体に摩擦応力はスタッドを使った場合より大をな值を示している。ての違 レは、㭘定曲線の違いによるものと思われる。

Fig.4 は CFD Kよる数値計算の結果 ${ }^{3)}$ で、乱流モデルKは 0 方程式モデルを使い、数值 計算のスキームK有限解析法（Finite Analytic Method）を使い、船首先端加ら乱流として 計算したものである。スタッドの位置から乱流であると仮定すれば、Fig.1(c)でスタッド より後方の位置で比較できるととになる。

\section{4 結言}

著者らが提案している壁面摩擦応力の非接触計測法を、船首付近の摩摖応力計測に適用 し、スタッドの勃果などを調查した。スタッドの無い場合は、層流と思われるので単純な 比較はできないものの、境界層の薄い場所での計測に本手法は有効である。をた、層流か ら乱流への遷移を議論することも課題の一つと思われる。 


\section{参考文献}

（1）奥野武俊他：油膜を用いた限界流線と壁面摩擦応力の計測、日本造船学会論文集、第 176 号、pp.59-65、1994

（2）奥野武俊他：可視化画像の時空間微分法を利用した流場の画像計測、関西造船協会誌、 第 216 号、pp.69-74、1991

(3) Tahara, Y. et. al.:Application of Isotoropic and Anisotoropic Turbulence Models to Ship Flow Computation, 第 27 回乱流シンポジウム講演論文集、pp.129 - 132、1995

(a)

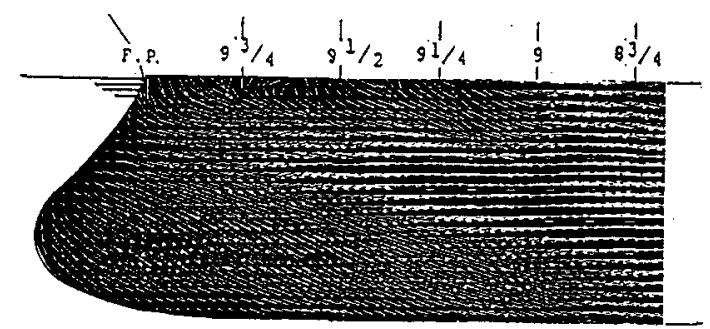

(b)

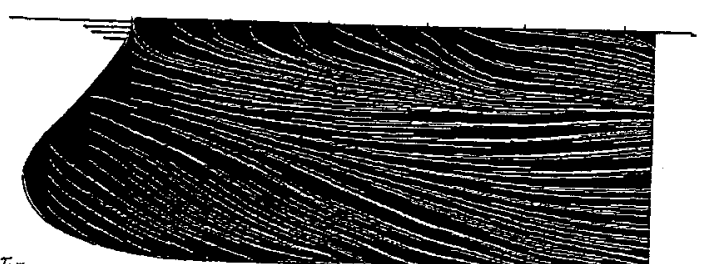

(c)

$C_{1}=\frac{\tau_{-}}{\frac{1}{2} \rho U_{*}^{2}}$

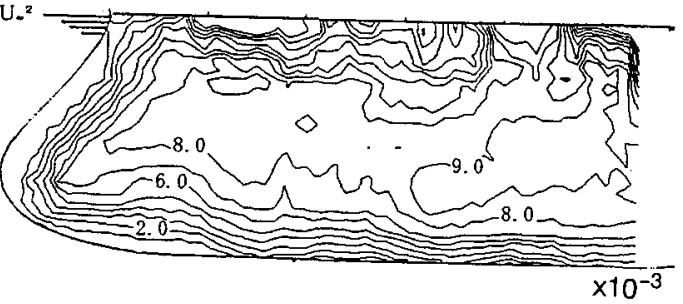

Fig.3 Measured results without turbulent stimulator.

(a)Displacement vectors of oil, (b) Limiting streamline, (c)Wall friction distribution (longitudinal component).

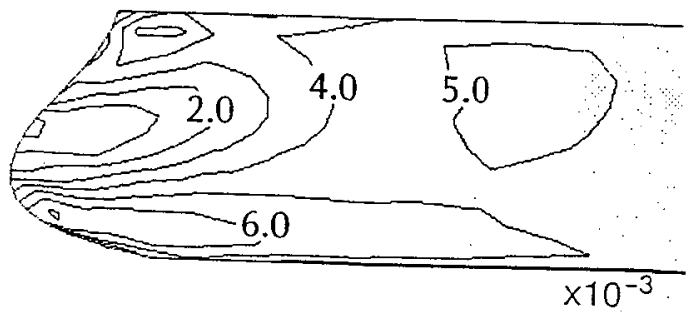

Fig.4 Calculated wall friction distribution. 